\title{
Como Hélio Oiticica chegou à Mangueira?
}

\section{Carla Hermann 1}

Resumo: $\mathrm{O}$ artigo aborda a obra de Hélio Oiticica a partir da incursão do artista ao Morro da Mangueira, no final de 1963. Com a análise da relação entre Oiticica e a cultura popular, vemos como a vivência na favela influenciou seus trabalhos, com destaque para os Parangolés (1966-68) e a Tropicália (1967).

Palavras-chaves: Hélio Oiticica, Mangueira, cultura popular, carnaval.

\section{How did Hélio Oiticia get to Mangueira?}

Abstract: The article analyses Hélio Oiticica work having his incursion o the Mangueira Hill in 1963 as a starting point. Through the relationship between the artist and Brazilian popular culture, we seek to understand how the favela experience had an effect on Oiticica's works, especially with the Parangolés (1966-68) and Tropicália (1967).

Keywords: Hélio Oiticica, Mangueira, popular culture, carnival.

\footnotetext{
${ }^{1}$ É doutora em História da Arte pela Universidade do Estado do Rio de Janeiro, onde defendeu tese sobre os panoramas oitocentistas em 2016. É mestre pela mesma instituição (2010) e possui graduação em Geografia pela Universidade de São Paulo (2003). Atua como geógrafa na Prefeitura Municipal do Rio de Janeiro desde 2010 e foi professora contratada do Departamento de Teoria e História da Arte da Universidade do Estado do Rio de Janeiro de 2017 a 2019. Seus atuais tópicos de interesse são: curadoria, paisagem, iconografia do Rio de Janeiro, produção artística do Século XIX, relação entre arte e natureza e relação entre arte e espaço urbano.
} 


\section{"Como cheguei à Mangueira"}

O título desse artigo deriva de um manuscrito do próprio artista. "Como cheguei à Mangueira" é um dos inúmeros escritos de Oiticica, notoriamente conhecido pela tradução escrita da sua preocupação documental e da reflexão teórico-filosófica acerca de sua obra e das influências que a cercaram. Esse documento não tem data, mas provavelmente foi escrito depois de 1964, ano da criação dos Parangolés, referenciados por Oiticica no texto. Nele o artista explica que foi levado à Mangueira pela primeira vez no final de 1963 por Jackson Ribeiro para assistir a um ensaio e que sentiu que precisava participar do samba:

Imediatamente senti que, para mim, não bastava 'assistir' e sim 'participar' do samba, do seu ritmo, do seu mito. Ao contrário do que poderia parecer, não há entre a minha arte como pintor um abismo instransponível, pelo contrário, toda a minha evolução artística caminha para o que chamo de uma expressão mítica essencial na arte. Há como que um cansaço do que é excessivamente intelectual e a busca do que é 'expressivo' na arte².

Sua experiência se expande para além de preparativos de Carnaval, e ele acaba por desenvolver laços com a comunidade, e essa vivência impregna a sua atividade artística. Há a ideia já bem estabelecida de que o contato com o samba e a marginalidade mudaram o foco das criações de Hélio Oiticica, quando a corporeidade e o marginal ${ }^{3}$ se mostraram como o vetor da sua experimentação. De fato, a biografia de Oiticica teve grande reverberação na sua obra artística e a sua chegada ao morro da Mangueira virou a chave para a dança e a corporeidade. Entretanto, é preciso esmiuçar como se deu essa relação para entender que tipo de apropriação Oiticica fez da cultura popular, e o caráter operativo que isso teve na sua obra.

Oiticica revela o que chegou à Mangueira levado pelo amigo, e que ali havia encontrado a "expressão mítica essencial da arte". Essa busca pela expressão está na gênese da questão neoconcreta, a qual Oiticica se afilia, mas também na necessidade dele da colocação do sujeito no mundo e a busca por um "engajamento" com ele.

\footnotetext{
2 Oiticica, Hélio. s/d. In: Sibila. Revista de poesia e crítica literária. Ano 20 - ISSN 1806-289X, jul., 2010.

3 Para ótima análise sobre como Oiticica se aproxima da questão da marginalidade, ver: Coelho, Fred. Heróis, anti-heróis e anônimos: marginalidade e extermínio em um texto de Hélio Oiticica. In: Cocco, Guiseppe et alii (org). Hélio Oiticica para além dos mitos. Rio de Janeiro: R\&L Produtores Associados, 2016. pp. 34-40.
} 
O historiador da arte italiano Guilio Carlo Argan ${ }^{4}$ coloca que o Expressionismo nasce "[...] como discriminação entre os impulsos autenticamente progressistas, por vezes subversivos, e a retórica progressista" o que encontra ressonância na crítica neoconcreta sobre o discurso concreto, dado como mecanicista e racional em níveis inaceitáveis e para os quais uma atitude de ruptura se fazia necessária. Não podemos deixar de encontrar semelhanças. A busca da arte como unidade e a totalidade da existência, "sem distinção possível entre sentido e intelecto, matéria e espírito"5 também aparece como a proposta de união entre sujeito e objeto, espaço da obra e espaço realistas na Teoria do Não-Objeto ${ }^{6}$. Ainda Argan nos coloca as influências filosóficas para as duas maiores vertentes impressionistas modernas, o movimento francês dos fauves e o movimento alemão Die Brücke. O primeiro sofreu influência direta de Bergson e da sua noção de que um único elã vital criativo determina o devir tanto dos fenômenos quanto do pensamento e que a consciência é a comunicação contínua entre sujeito e objeto, enquanto que o segundo fez leituras diretamente sobre a fonte alemã nietzscheniana onde a consciência se equivale à própria existência, mas existe enquanto luta sobre a rigidez dos esquemas lógicos e a inércia do passado que oprime o presente. Apesar das duas matrizes filosóficas serem distintas, não somente o problema que estes expressionismos procuram resolver é o mesmo, o da contradição histórica entre clássico e romântico, como ambos se utilizam de pensamentos que procuram colocar a existência como fundamentadora da percepção sobre o mundo, exprimindo questões interiores sobre ele.

Não é por acaso que o crítico Ronaldo Brito $^{7}$ reconhece dentro do pensamento do racionalismo construtivo brasileiro um "Nietzsche exótico" e uma contradição na sua gênese. O mesmo pode ser dito sobre a conformação do pensamento de Hélio, onde também está presente este caráter sensual nietzscheniano. De fato, as duas fontes expressionistas supracitadas - Nietzsche e Bergson - são

\footnotetext{
${ }^{4}$ Argan, Giulio Carlo. Arte Moderna. São Paulo: Companhia das Letras, 2006. p. 227.

${ }^{5}$ Argan, 2006, p. 228.

${ }^{6}$ De autoria de Ferreira Gullar, a Teoria do Não-Objeto foi publicada em edição do Suplemento Dominical do Jornal do Brasil em 1960 como contribuição à II Exposição Neoconcreta, que ocorreu entre 21 de novembro e 20 de dezembro de 1960.

${ }^{7}$ Brito, Ronaldo. Neoconcretismo. Vértice e ruptura do projeto construtivo brasileiro. São Paulo: Cosac \& Naify, 2002.Brito, 2002. p. 81.
} 
constantemente recuperadas nos seus escritos. "É com euforia que Oiticica cita Nietzsche, Malevitch, Bergson, entre outros, ao perceber nos trabalhos destes inventores passagens que confirmam e expandem suas ideias como a valorização do corpo, o suprasensorial ou o experimental"8. A reunião desta dimensão sensível não formalizável só poderia ser pensada pelo neoconcretismo no "registro do sublime, isto é, no âmbito tradicional da estética idealista" 9 . A contaminação da estética neoconcreta por um certo idealismo tem a tradução no conceito de expressão ou de organicidade (para frisar a questão de unidade sensível e formal). Se a leitura concreta lidava com um idealismo tecnicista da forma que ignorava o campo sobre o qual a arte operava, a visão neoconcreta recupera o idealismo clássico pelo viés expressivo.

É dentro da contradição entre este idealismo e a vontade de executar obras totais e sensíveis que Hélio vai trabalhar a cor e sua capacidade expressiva. Pensando a questão expressiva como a maneira do sujeito se colocar no mundo, Oiticica aproxima a imanência sensível da cor do sentido de expressão pessoal como tarefa central da obra de arte. Ao darmos continuidade à leitura de "Como cheguei à Mangueira", lemos que a expressão, para ele, havia sido encontrada na pulsão da dança, despertada pelo samba mangueirense:

Para mim, havia um impulso interior forte que me induzia ao ritmo, à dança.

Como pintor, havia eu chegado ao que chamo de "pintura no espaço".

Da arte concreta à neoconcreta (correntes da arte abstrata que se caracterizaram pela geometrização formal e busca de um espaço novo na pintura), caminhar para uma expressão própria, levando a cor além do limite do quadro. A pintura não se dá aqui, dentro do quadro, mas em estruturas especiais, que podem ser Núcleos, Penetráveis e Bólide.

Em 1964 criei também, dentro disso, o que chamo de Parangolé, que seria a cristalização mais original dessa experiência. A participação do espectador, nas obras de que falei, chega no Parangolé a um elemento mais corporal e apela instintivamente ao ritmo: o espectador corre ou dança com a obra, pois esta não é apenas contemplativa, mas pede dele a participação direta. Penso mesmo em um "espetáculo-Parangolé", que seria realizado durante uma exposição continuamente,

\footnotetext{
8 Braga, Paula Priscila. A trama da terra que treme: multiplicidade em Hélio Oiticica. [tese de doutorado] São Paulo: Universidade de São Paulo, 2007. p. 11.

${ }^{9}$ Brito, 2002, p. 93.
} 
já que para mim uma "exposição" seria diferente do que se costuma supor: a participação dos espectadores já pode dar uma ideia da forma que assumiria. ${ }^{10}$

\section{Núcleos, Penetráveis e Bólides}

Oiticica resume, nesse trecho do seu pequeno texto, aquilo que ele chamava de "transição da cor do quadro para o espaço"11. Nos primeiros anos da década de 1960, o artista desenvolveu os Núcleos e Penetráveis, onde o espectador era investido de poder de escolha no funcionamento dos elementos espaciais. A experimentação avançou por duas linhas de investigação: a da visão contínua da estrutura-cor (na exploração das múltiplas possibilidades de direções a serem tomadas no espaço e da ressonância da cor nele) e a da efetivação da participação. As duas diretrizes iriam se fundir naquilo que Oiticica chamava de "vivência da cor". Os Núcleos (1960-63) eram formados por placas de compensado de madeira pintadas de cores fortes e penduradas no teto do espaço expositivo, ou seja, longe das paredes como um quadro. Convidavam as pessoas a caminharem por eles, criando espacialidade para a cor, que abarcava o público. Já os Penetráveis (1960-66) eram estruturas verticais, como caixas nas quais se podia adentrar. Também eram feitos com madeiras de acabamento pobre, pintadas de maneira rústica e em cores fortes. O Penetrável significava a possibilidade literal de entrar na obra, concretizando a vontade do artista de possibilitar ao espectador a participação ativa e obrigatória, porque é no espaço da caixa que a obra se dá.

Quando menciona os Bólides no texto acima, Oiticica se refere aos primeiros exemplares dessa série de objetos, cuja produção se estendeu entre os anos de 1963 e 1969, ou seja, teve início pouco antes da sua chegada à Mangueira, e perdurou por alguns anos, acompanhando sua vivência no morro. Os Bólides são pequenas arquiteturas ambientais, onde a cor escolhida enche os objetos de luz. Os Bólides-caixas são pensados para a manipulação, com painéis móveis capazes de revelar novos planos cromáticos. Os compartimentos e aberturas (alguns visíveis, outros não) contêm pigmentos, espelhos e outros materiais. O artista se referia a eles como "estruturas para inspeção", e tal como os Núcleos e Penetráveis, eram de madeira mal pintada em cores fortes.

\footnotetext{
10 Oiticica, s/d.

${ }^{11}$ Oiticica, Hélio. Aspiro ao grande labirinto. Rio de Janeiro: Rocco, 1986. p.50.
} 
Aos Bólides-Vidro são introduzidos mais elementos do dia-a-dia, cotidianos, tais como recipientes de vidro, plásticos, terra, juta, conchas. As possibilidades de interação tátil e visual são expandidas significativamente. As cores das obras agora vão além dos brancos, amarelos e vermelhos até então utilizados por Oiticica: rosas e azuis estão incluídos. Com o uso de uma materialidade rústica e mal acabada, com o posicionamento dos objetos no chão e com a presença de materiais de aspereza tátil, Oiticica criou objetos de manipulação, mas que não eram tão convidativos, chamando o público a uma participação $\operatorname{adversa}^{12}$.

Seguindo o texto de Oiticica sobre a Mangueira, chegamos aos Parangolés, obras que ele mesmo definiu como "ponto crucial" do seu desenvolvimento teórico da estrutura-cor no espaço ${ }^{13}$. São capas vestíveis, feitas de materiais diversos, como panos, plásticos, esteiras, cordas, com partes costuradas e vez por outra, algum dizer. Os que vestem os Parangolés precisam se mover. É essa dança, no balançar dos braços, que preenchem o espaço, numa "participação ambiental"14 E é dessa experiência que vem a expressão. Mais uma vez, encontramos nas palavras do próprio artista essa constatação. Em entradas em seu diário, em algum dia entre novembro de 1964 e novembro de 1965, ele coloca: "A ação é a pura manifestação expressiva da obra. (...) O próprio 'ato de vestir' a obra já implica uma transmutação expressivo-corporal do espectador, característica primordial da dança, sua primeira condição"15. Essa condição da dança impede que a obra seja estática, contemplativa: o Parangolé que repousa num cabide no espaço expositivo não faz sentido. Ele só existe efetivamente no movimento. É como toda a materialidade do samba e do carnaval: instrumentos, tambores, roupas e fantasias documentam a experiência, mas parados em um museu não são capazes de sequer começar a descrevê-la.

Embora diga estar mais preocupado com a estrutura do que com os materiais e a forma, Oiticica usa a imagética do samba e as cores da Escola de Samba Estação Primeira de Mangueira para organizar essas

\footnotetext{
12 Para maior desenvolvimento sobre o sendo de adversidade na série dos Bólides, ver Hermann, Carla. A materialidade e o adverso nos Bólides de Hélio Oiticica. Rio de Janeiro: Edições Mundo Contemporâneo, 2017. 126p.

13 Oiticica, 1986, p. 65.

${ }^{14}$ Oiticica, 1986, p. 67.

${ }^{15}$ Oiticica, 1986, p. 70.
} 
obras. Os três primeiros Parangolés seriam compostos por tendas, estandartes e bandeiras, elementos que exigem um "percurso do espectador"16. O Parangolé P4 viria a ser a primeira capa a ser vestida. "Qual a relação disso tudo com o samba da Mangueira?17" indaga o artista em seu texto.

Antes de tudo, devemos nos lembrar de que o indivíduo, principalmente o artista, se constitui em uma totalidade, um bloco inteiro de personalidade, em que as partes, apesar de às vezes antagônicas, são indivisíveis. A relação, pois, que há entre uma atividade e outra, longe de ser ditada por conceitos exteriores, vem de dentro, desse núcleo que é a personalidade. Fatalmente, na minha experiência, seria eu levado a essa busca do ritmo, da dança na sua forma mais mítica, que é a dança popular, baseada mais em ritmos que em coreografias.

Talvez Hélio Oiticica estivesse explicando porque, apesar de sua herança neoconcreta (que defendia a obra encerrada em si mesma), ele havia encontrado na dança, no pulsar do ritmo, a resposta para os anseios de se expressar e engajar-se com o mundo. E colocando que sua ida a Mangueira vinha atender um anseio pessoal. O crítico e historiador Michael Asbury defende que o contato com a cultura da favela não representou uma ruptura de Oiticica com as teorias da forma sensível da proposição do Neoconcretismo. O que havia mudado era seu entendimento acerca do popular.

$\mathrm{Na}$ realidade, o entendimento da classe artística sobre a arte popular havia mudado de maneira geral. O governo de João Goulart (1961-64) foi um período de radicalização social e grande mobilização política, tendo como novidade a participação da classe média - e artística - nos partidos políticos. Essa participação cotidiana política vinha acompanhada de certa consciência de classe artística, e da reivindicação de que o engajamento cultural deveria refletir a produção das obras. Esse debate aconteceu em meio à presença ainda forte de uma ideologia nacionalista que acreditava no progresso e que, desde os anos 1950, estimulava a atuação da arte concreta cerrada nela mesmo, na sua relação com a técnica e a indústria. Se no debate estritamente artístico o neoconcretismo abria a forma ao sensível, e acreditava na experiência como a realização da obra, no campo do debate político social surge nesse momento uma arte engajada, que visava a tomada de consciência e a valorização da cultura popular. Foi no seio da União Nacional dos

\footnotetext{
16 Oiticica, 1986, p. 68

17 Oiticica, s/d.
} 
Estudantes - UNE, em 1961, que um grupo ligado ao teatro criou o Centro Popular de Cultura - CPC, para tratar a cultura popular como forma de consciência política.

Asbury nos fala que a possibilidade de engajamento com as classes populares fez com que alguns artistas enxergassem a pertinência política em suas atividades. As mudanças no diálogo entre Hélio e Ferreira Gullar (ou das divergências entre eles), é significativa disso, visto que o poeta, que havia sido o principal teórico do movimento neoconcreto, abandona a prática vanguardista para se envolver com os CPC em 1961, a ponto de tornar-se presidente dele no ano seguinte ${ }^{18}$. A partir de então, Oiticica e Gullar trilharam caminhos muito diferentes, já que Hélio não tinha a intenção de se afastar da posição de vanguarda. Ele resolveria a questão da participação do espectador de sua obra, que passava a ser participador através da cor e trabalharia a necessidade de engajamento com o mundo através de questões artísticas menos obviamente politicas. Mas principalmente, porque o projeto dos CPC era o de simplificar conceitos políticos e torná-los reconhecíveis para a massa da população. Essa ideia condescendente jamais o seduziu.

Para Oiticica, nunca houve a questão da simplificação. Ele se infiltrou naquela cultura [A Mangueira] não porque estivesse conscientemente tentando construir uma ponte entre cultura erudita e cultura popular, mas porque esta o atraía como indivíduo. ${ }^{19}$

Se a interpretação de Asbury é correta, Hélio chegou à chave para sua expressão ao atender um desejo interno de libertação pela dança, foi a sua descoberta da favela que o tornou "capaz de associar a noção de intuição e seu ideal de sublime através da exuberância popular do samba e do carnaval"20. Para Oiticica, a ideia do sublime passava por Goethe, conforme anotado em 21 de janeiro de 1961 em seu diário:

Goethe: "Mas o certo é que os sentimentos da juventude e dos povos incultos, com sua indeterminação e suas amplas extensões, são os únicos adequados para o 'sublime'. A sublimidade, se há de ser despertada em nós por coisas exteriores, tem que ser 'informe' ou consistir de 'formas inapreensíveis', envolvendo-nos numa grandeza que nos supere... Mas assim como o sublime se produz facilmente no crepúsculo e na noite, que confundem as figuras, assim também se desvanece no

\footnotetext{
${ }^{18}$ Asbury, Michael. O Hélio não tinha ginga (2006). In: Braga, Paula Priscila. (org.) Fios soltos: a arte de Hélio Oiticica. São Paulo: Perspectiva, 2008. p. 37.

${ }^{19}$ Asbury. 2008, p. 40.

${ }^{20}$ Asbury. 2008, p.41.
} 
dia, que tudo separa e distingue; por isso a cultura aniquila o sentimento do sublime. ${ }^{21}$

Sem anotar de onde a citação havia sido tirada, Hélio Oiticica conclui que o parágrafo copiado resume de maneira genial sua inquietação e a mobilidade que ele sentia do sublime. A certeza que Hélio adquire a partir disto é a de que a obra não pode jamais ser apreendida, devendo ser "[...] eternamente móvel, cambiante"22, condição necessária para seu entendimento de que seu trabalho estará sempre em progresso. A dança e a certeza da impossibilidade de apreensão e congelamento do tempo vêm atender isso.

\title{
Parangolés
}

Ainda na perseguição do sublime, Oiticica incorre no romantismo, ao narrar a tradição expressiva do samba, e acaba admitindo que reconhecia nessa força vital a origem das coisas:

\begin{abstract}
A Mangueira, para mim, é como se existisse há 2 mil anos: como expressão, o seu samba possui algo de arcaico, como se nascesse da terra; não me impressiona tanto a "tradição", mas o arcaísmo que contém a sua expressão. Na sua maneira de ser há algo que nos leva às origens das coisas.

Foi o grande passista Miro quem me introduziu nos primeiros passos do samba; seu pai, Pedro da Dinda, um dos fundadores da Escola (pandeirista, sapateador e compositor excelente), e sua mãe, Dona Didi, que faz cabeleiras e perucas com habilidade de uma verdadeira artesã; um dos seus irmãos é também compositor. Vê-se, pois, aí, uma verdadeira família de artistas, empenhados em fazer o que fazem benfeito, da melhor maneira possível. Não é esse um dos requerimentos da arte?23
\end{abstract}

Ele faz questão de registrar que foi um dos detentores desse saber - o filho de um dos fundadores da Escola - que o iniciou nos passos do samba. Registra que Miro, Pedro da Dinda e Dona Didi, formam uma família de artistas, afinal, artistas fazem benfeito aquilo que se propõem a fazer. Hélio Oiticica equivale o seu ofício de artista aos dos artistas que conheceu na Mangueira. Nomeia outros passistas e sambistas, como

\footnotetext{
${ }^{21}$ Oiticica, 1986, p. 26.

22 Oiticica, 1986, p. 26.

${ }^{23}$ Oiticica, s/d.
} 
Nininha, cujo rebolado carrega "todo o ritmo da raça negra"24. Conta que troca aulas de pintura por aulas de samba com um adolescente que é passista promissor. Apaga as fronteiras entre arte popular e erudita, da qual ele, Oiticica, participa. E o faz impressionado e respeitosamente, mas não consegue evitar reafirmar a diferença entre as duas culturas. Embora negue, Oiticica parece buscar uma certa pureza, crendo que no popular residia aquilo que a arte erudita não poderia dar conta jamais. $\mathrm{O}$ Parangolé seria a tentativa de unir a arte ao elemento mítico que ele havia descoberto. Tal como a música, o samba, sempre cambiante, nunca estanque.

Nada mais lógico que, ao se aproximar a minha arte do mito, da vivência mítica essencial, encontrasse eu na dança uma relação objetiva e fundamental.

A criação do Parangolé nasce dessa necessidade do que chamo de "nivelamento cultural"; é uma aproximação da arte com o seu elemento mítico. Não se trata de um folclorismo superficial que até agora só tem servido de demagogia na arte, mas de uma vivência expressiva das origens, dentro dessa evolução da arte de hoje, onde poderia enquadrar a minha experiência. ${ }^{25}$

Embora Oiticica dissesse que não importava a "apreensão objetiva transporta dos materiais que constitui a obra" 26 , negando a origem dos materiais ou o que eles representam, é claro que a escolha da matéria fala do lugar que o artista queria ocupar e de como isso estrutura sua obra. A escolha das cores da Escola de Samba para alguns Parangolés, e o uso de dizeres que falavam diretamente da Mangueira faziam com que o mundo artístico fora da favela soubesse da descoberta que ele havia feito da cultura do samba e do carnaval como potência criadora.

\footnotetext{
24 Oiticica, s/d.

25 Oiticica, s/d.

${ }^{26}$ Oiticica, 1968, p. 65.
} 
Imagem 1 Miro da Mangueira com P4 Parangolé Capa 1, 1964 Foto Desdemone Bardin in RAMIREZ, Mari Carmen. Hélio Oiticica: The Body of Color. Londres:

Tate Publishing, 2007, p. 304

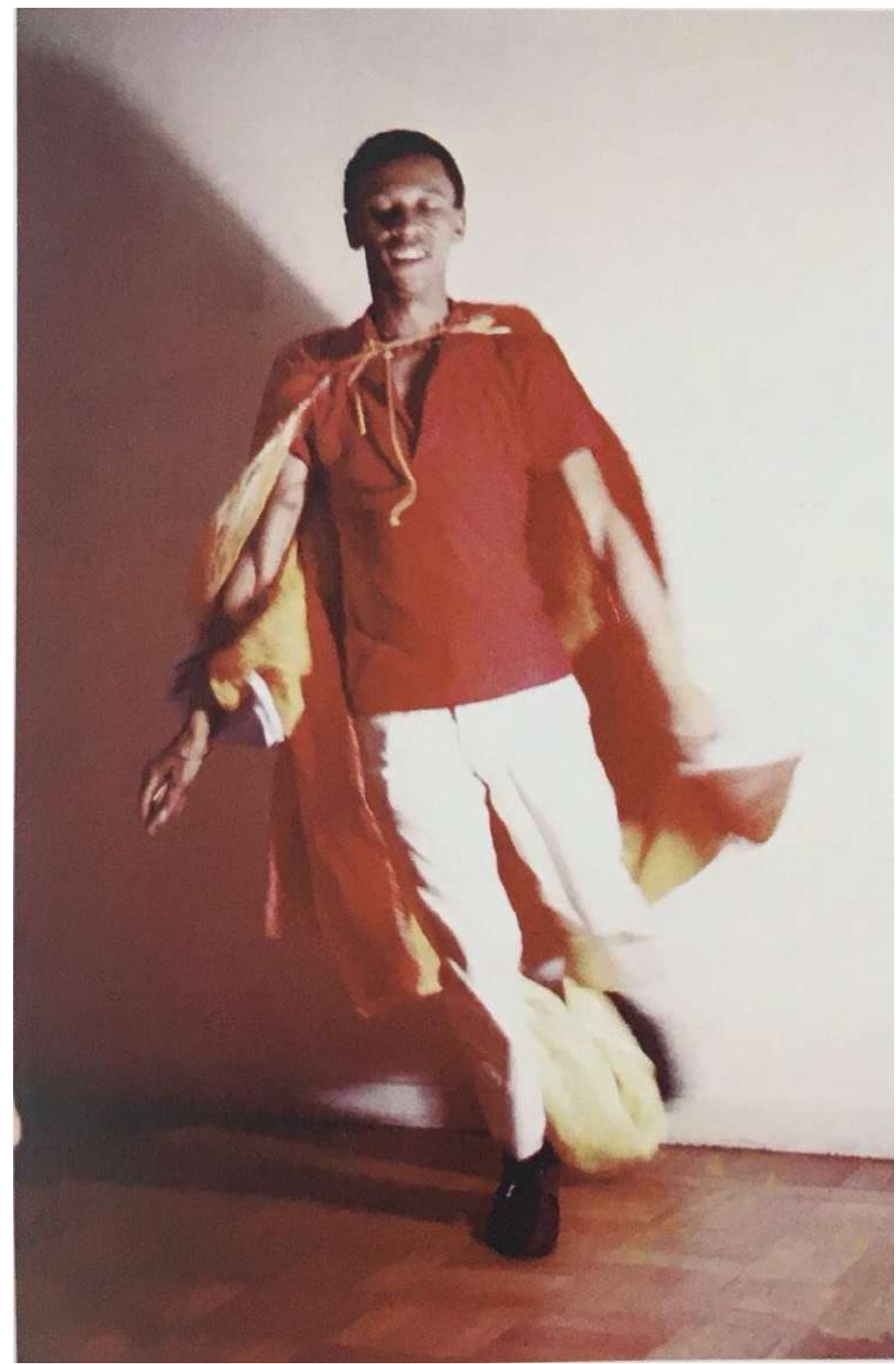

O texto "Como cheguei à Mangueira" termina dizendo que, para entender essa magia do samba, é preciso participar.

Das expressões populares, é o samba das escolas o que mais me interessa como elemento de unificação cultural. É impossível dar aqui a ideia da riqueza de inspiração do seu ritmo, das suas músicas, da majestosa plasticidade da encenação dos seus desfiles: assistir a um deles equivale a uma emoção única em toda a vida. 
Participar então, nem se fala. ${ }^{27}$

Imagem 2

Jerônimo da Mangueira com P8 Parangolé

Capa 5 "Mangueira", 1965 in RAMIREZ, 2007, p. 310

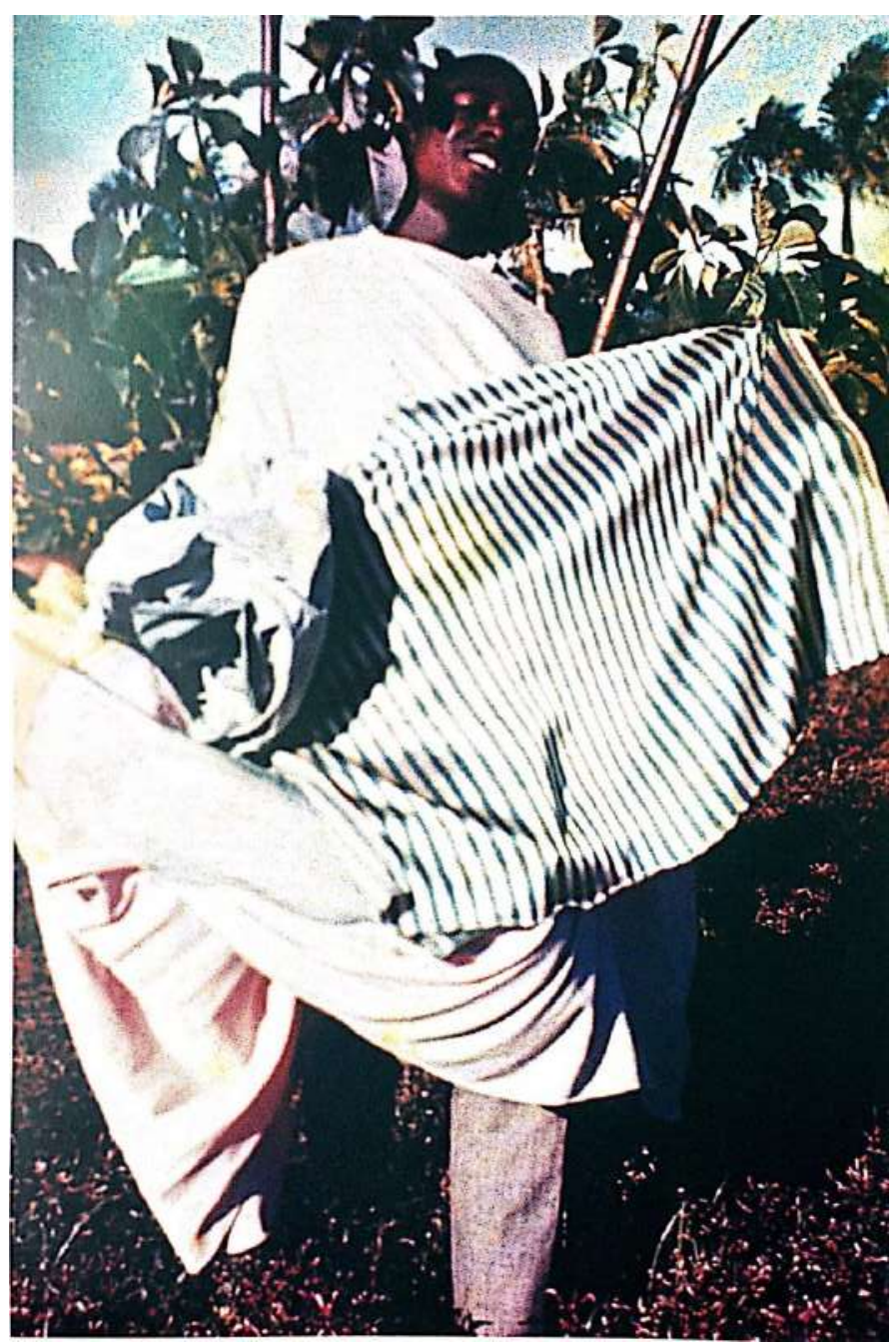

Afinal, qual é o entendimento de Oiticica sobre arte/cultura popular? Para o crítico paraguaio Ticio Escobar, o termo "popular" nomeia posição assimétrica de certos setores com relação a outros, considerando os fatores plurais que interveem nas situações de subordinação. Estas, por sua vez, são entendidas a partir de distintas formas de opressão, exploração, marginalização ou discriminação realizadas em diferentes âmbitos (políticos, econômicos, culturais, sociais, religiosos, etc.) em prejuízo de setores que resultam, assim, excluídos de uma participação efetiva em qualquer um desses âmbitos. "A arte popular mobiliza tarefas de construção histórica, de produção de subjetividade e de afirmação de diferenças. Esse momento constitui um referente fundamental de identificação coletiva e, portanto, um fator de 
coesão social e contestação política"28. Ou seja, apesar de Hélio Oiticica não denominar a cultura popular como um campo de interesse direto seu, ela parece funcionar perfeitamente para sua obra como uma categoria operativa, como esse lugar onde a oposição à essa estética da "grande arte" reside e onde está o elã do mundo, a força incapaz de apreender, sublime. Reverbera, aqui, a afirmação que Oiticica copiou de Goethe no seu diário em 1961, se entendermos que Goethe chama de "cultura" aquilo que hoje comumente chamamos de cultura ocidental29.

Na sua vivência no Morro da Mangueira, Oiticica costumava levar para o ambiente da favela alguns de seus Bólides e Parangolés, objetos que tinham como admitida referência inicial algum momento vivido ou observado pelo artista de situação de precariedade. Toda a vivência de Hélio na Mangueira foi também em busca pela margem da cidade, e é nessa margem que ele encontra o mito.

Em 1965 sua amiga Desdemone Bardin fez fotos identificadas por Oiticica como "a gênese dos Parangolés"30. As fotografias trazem objetos despejados em locais de relativo abandono. A primeira mostra Hélio e Jackson Ribeiro, em um terreno ao lado da linha do trem, observando uma faixa de tecido com dizeres pendurada por um único ponto, formando uma pequena cobertura, como uma pequena barraca ou tenda. A segunda mostra uma pilha de latas, formando um retângulo irregular, tendo sido clicada nos arredores da Mangueira. A terceira também dispõe poucas latas, uma garrafa de bebida e um saco plástico preto ao pé de uma árvore franzina, onde há alguns pedaços de panos ou plástico, tirada no estacionamento do Museu de Arte Moderna do Rio de Janeiro. As fotografias, capturas de momentos visivelmente organizados pelo artista a partir do lixo e usando objetos largados nos locais, permanecem como documentos visuais dessa noção de que os Bólides e os Parangolés seriam abstrações da própria condição de precariedade encontrada nas ruas. Além disso, como as fotografias foram feitas em espaços marginais (terrenos vazios cheios de lixo e entulho ao lado da linha do trem e próximos à favela, ou mesmo um estacionamento), tornam irresistível a ideia de que os seus Parangolés tomaram forma a partir dessa condição urbana marginal. Os espaços

\footnotetext{
${ }^{28}$ Escobar, Ticio. El mito del arte y el mito del Pueblo. Cuestiones sobre arte popular. Santiago do Chile: Ediciones Metales Pesados, 2008. p.13.

29 Oiticica, 1986, p.26.

${ }^{30}$ Ramirez, 2007, p. 374.
} 
produzidos pela urbanidade como excessos que constituem vazios seriam abjetos da metrópole, sobras do uso "oficial" da cidade. Seriam estes espaços ideais para Hélio, que aproveitaria também a noção daqueles espaços como o informe, inominado, que estrutura as obras. A favela era e é lugar às margens da cidade, não regida pelo poder "oficial".

O achar na paisagem do mundo urbano, rural etc. elementos "Parangolé" está também aí incluído como o 'estabelecer relações perceptivo-estruturais' do que cresce na trama estrutural do Parangolé (que representa aqui o caráter geral da estrutura-cor no espaço ambiental) e o que é 'achado' no mundo espacial ambiental. $\mathrm{Na}$ arquitetura da 'favela', por ex., está implícito um caráter do Parangolé, tal a organicidade estrutural entre os elementos que o constituem e a circulação interna e o desmembramento externo dessas construções, não há passagens bruscas do 'quarto' para a 'sala' ou 'cozinha', mas o essencial que define cada parte que se liga à outra em comunidade.

Em 'tabiques' de obras em construção, p. ex., se dá o mesmo, em outro plano. E assim em todos esses recantos e construções populares, geralmente improvisados, que vemos todos os dias. Também feiras, casas de mendigos, decoração popular de festas juninas, religiosas, carnaval, etc. ${ }^{31}$

Portanto, Oiticica encontrou na cultura popular (em seus diversos aspectos materiais e imateriais) a estrutura de caráter universal que Oiticica buscava com desde os Penetráveis, Núcleos e Bólides. A partir da sua entrada na Mangueira a cultura se firma como agente provocador de fricção para sua obra. Embora pretendesse um sentido político para seus trabalhos, jamais o fez através de frases de efeito e imagens de óbvia conotação política. Defensor da necessidade de "[...] colocar no sentido social bem claro a posição do criador, que não só denuncia uma sociedade alienada de si mesma mas propõe, por uma posição permanentemente crítica, as desmitificação dos mitos da classe dominante $[\ldots]^{\prime \prime 32}$, Hélio compreendia que o papel do artista seria também sócio-político. Sendo tão individualmente envolto nas questões acerca da arte da natureza do objeto e da pureza pelas cores, nada mais pertinente do que pretender se colocar criticamente através das formas abstratas e menos explícitas, numa tomada de posicionamento subterrâneo. Diante do sentido de uma cultura exterior que seria por ela mesma, adversa, um dos mecanismos dos quais Oiticica se utiliza é o de criar adversidade, e assim devolver o espectador para o mundo.

\footnotetext{
${ }^{31}$ Oiticica, 1986, p. 68.
}

32 Figueiredo, Luciano. (org.) Lygia Clark Hélio Oiticica: cartas 1964-74. Rio de Janeiro: Ed. UFRJ, 1996. p. 74. 
Os efeitos do uso da cultura para tensionar seus objetos, efeito direto da experiência na favela, são bem documentados com fotografias das obras e de sua fruição, numa espécie de registros das experiências conduzidas por Oiticica á época. O B09 Bólide Caixa 71964 (ou seja, realizado após o início da experiência mangueirense) é um exemplo contundente dessa dualidade entre a interioridade de um objeto abstrato e a cultura. A precariedade proposital da sua construção faz com que o reflexo daquele que olha para seu interior transponha o observador para dentro da situação adversa. Ao mesmo tempo, torna o Bólide parte integrante do seu fora. Enfim, borra as fronteiras entre o interior e o exterior da caixa, afirmando, de maneira dupla, a adversidade do precário.

As fotografias abaixo, realizadas a pedido de Hélio Oiticica em 1964 por Andreas Valentim em uma viela no morro da Mangueira escancara essa relação. Na primeira foto o B09 Bólide Caixa 7 reflete a perna magra de um morador da favela, e que deixa revelar, atrás de si, uma bacia de alumínio apoiada sobre uma pedra e uma camiseta pendurada para secar. Em tão pouco espaço mostra muita coisa: trabalho manual e árduo, com a peça de roupa e a bacia, num lugar de rugosidades - chão de cimentos, paredes de madeira, pedras que apoiam as coisas. Nada disso se assemelha à isenção do espaço do museu onde aquele supostamente poderia estar. Essa aspereza se associa à materialidade bruta do próprio Bólide, como se ele fosse, de maneira independente de onde está, um objeto causador dessa adversidade. Na segunda fotografia, um morador da favela, de cócoras, se posiciona à frente ao mesmo B09 Bólide Caixa 7. Ao fundo, na imagem, algumas pessoas participam da cena. Uma jovem come algo de pé na porta de casa, mas sem olhar para o objeto artístico. Ao seu lado um homem caminha, de calça xadrez e com a camisa aberta, cujo olhar parece se direcionar a outra coisa que não o Bólide e a contemplação do rapaz em questão. Entre o homem de camisa aberta e a moça, vemos ainda a silhueta de alguém que veste short, estando apenas a perna aparente em uma esquina da viela. Essas pessoas, moradoras da favela, parecem viver suas vidas sem considerar o Bólide uma interferência. A única pessoa no plano de fundo da imagem que percebe a contemplação do Bólide é um homem com máquinas fotográficas pendurada no pescoço e mão na cintura, olhando com interesse o que acontecia. Caracterizado como um observador exterior, ele denuncia que por maior naturalidade que parecesse a presença do Bólide no chão da viela da favela, aquele objeto, na verdade, vinha de fora. 

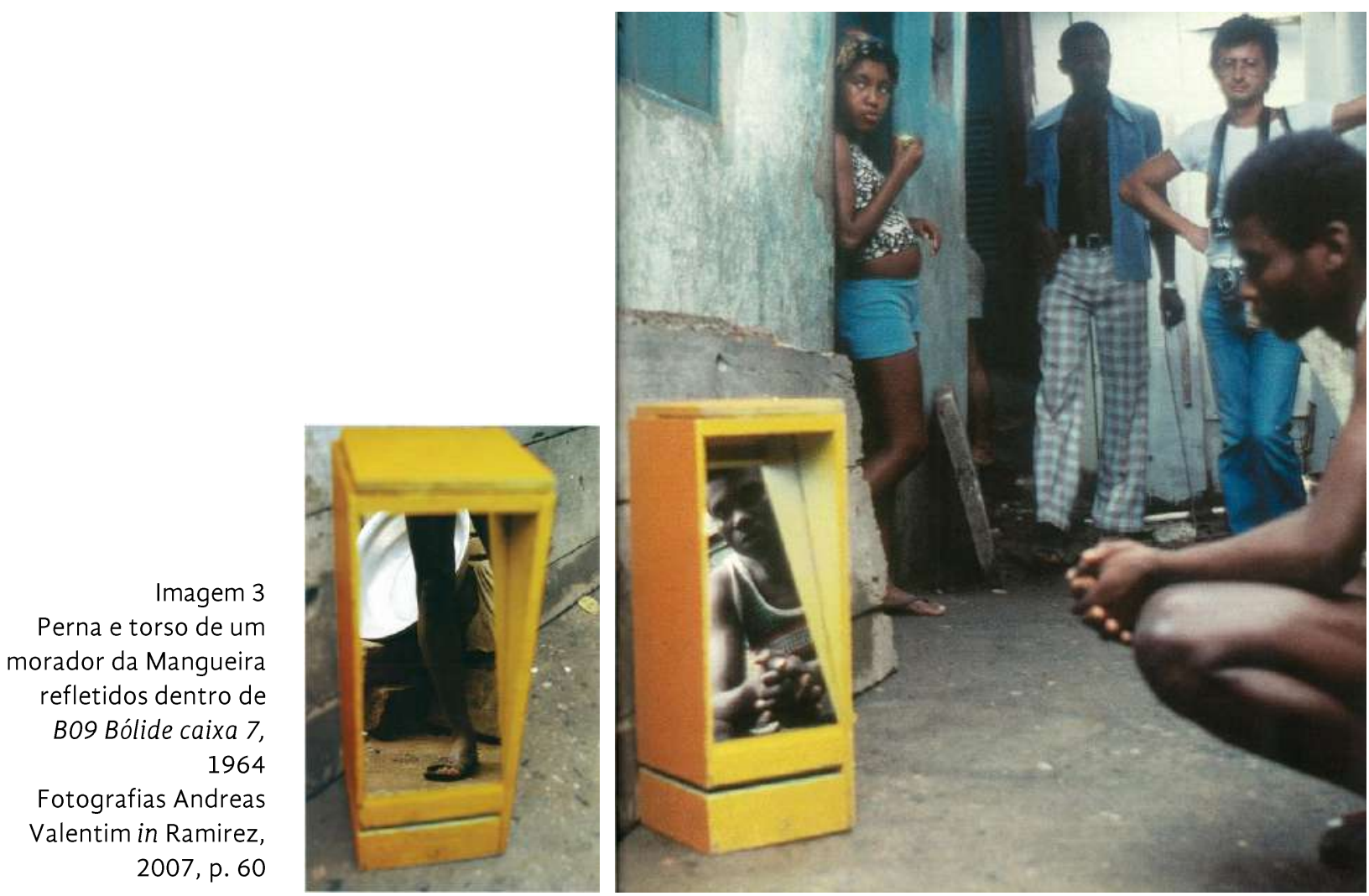

No primeiro plano, o rapaz de cócoras que contempla o Bólide olha para o objeto e o espelho em seu interior devolve o olhar do rapaz a nós, espectadores da foto. O espelho reflete o rapaz - vemos que ele tem as mãos cruzadas, veste uma camiseta regata escura com borda branca - e reflete também uma parte da estrutura amarela de madeira. Parece que é a resposta para Oiticica: é preciso incorporar essa cultura exterior onde ele havia encontrado as respostas de um "caráter universal" em suas obras, sua materialidade. Os Parangolés realizam isso com maestria, e a Tropicália, que seria realizada alguns anos depois, construiria, dentro do espaço do museu, uma obra ambiental com esses elementos.

Outro registro notável é uma série de fotografias sem autor conhecido, realizadas em 1965 e que mostram o passista-mirim Mosquito da Mangueira dançando com o Parangolé P10 Capa 6 junto ao B17 Bólide Vidro 5 Homenagem a Mondrian em uma calçada. Descalço, o menino samba junto ao Bólide. A parte frontal da capa que ele veste diz "Sou o mascote do Parangolé, Mosquito do Samba", ou seja, é uma obra que Oiticica pensou para Mosquito, a quem costumeiramente tecia elogios quanto às habilidades de dança e com quem parece ter desenvolvido 
uma relação de parceria ${ }^{33}$. Novamente, o Bólide não está no espaço do museu, e sim num espaço comum. Nesse caso, uma calçada de pedrasportuguesas em uma rua que parece ser na zona sul da cidade do Rio de Janeiro. O menino Mosquito performa sua dança também um tanto deslocado dos locais em que costuma dançar. A suposta neutralidade do espaço público, lateral ao asfalto (em oposição ao chão de terra batida no morro da Mangueira) escancara um atrito cultural entre a arte moderna na qual estava inserido e a cultura popular que ele reconhecia como total e mítica, ao mesmo tempo que mostra a solução tomada por Oiticica. O Bólide, com sua base de vidro repleta de pigmento amarelo em suspensão em água, coroado por um emaranhado de tela de nylon e tecido pintados em azul e vermelhos esmaecidos, presta homenagem a Mondrian, importante representante da herança construtiva de Oiticica. A busca pelo absoluto metafísico, da abstração universal de Mondrian encontra reverberação na organicidade de Mosquito da Mangueira, escolhido o "Mascote do Parangolé" ao vestir a capa e dançar, percorrendo a ritualística pensada pelo artista para trazer à tona trazendo elemento mítico ${ }^{34}$ almejado por Oiticica.

\footnotetext{
33 Encontramos diversas fotografias do Mosquito da Mangueira, passista-mirim, interagindo com obras de Hélio. Por exemplo, as imagens de autoria desconhecidas: Mosquito da Mangueira contempla Relevo Espacial, 1959 em Galeria C4, Rio de Janeiro, 1964; além de Mosquito da Mangueira com Parangolé P4 Capa 1 abrindo Bólide Plástico 1, 1966 e Mosquito da Mangueira com Bólide Luz 01 - Apropriação 03 Platiscópio, 1965. In: DERCON, Chris et alii (org). Hélio Oiticica (catálogo). Rio de Janeiro: Centro de Arte Hélio Oiticica, 1998.

34 Oiticica. s/d.
} 
Imagem 4 Mosquito da Mangueira com P10 Capa 6 junto ao $B 17$ Bólide Vidro 5 Homenagem a Mondrian, 1965 Fonte: Projeto Hélio Oiticica

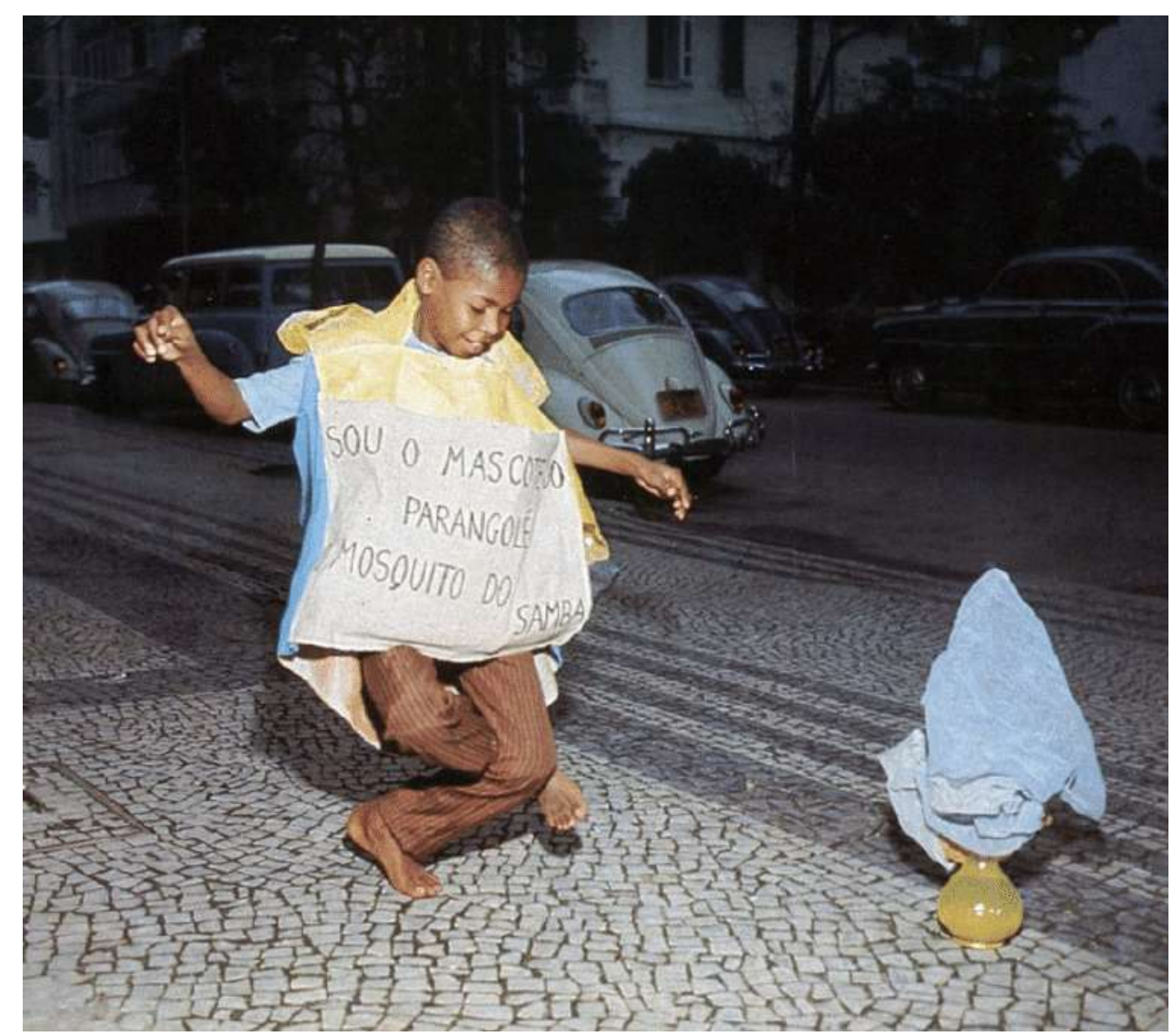

\section{A Tropicália}

A catálise mangueirense no processo criativo em progresso de Oiticica toma forma especialmente na exposição-evento Tropicália, realizada no Museu de Arte Moderna no Rio de Janeiro em abril de 1967. A Tropicália resulta diretamente das suas experiências com a arquitetura orgânica da favela, e das passagens labirínticas do Morro da Mangueira.

Tropicália é composta de dois Penetráveis, PN2 - Pureza é um mito (1966) e PN3 - Imagético (1966-67), além das plantas tropicais em vasos de barro, areia, terra, pedregulhos e serragem no chão, capas de Parangolé e um aparelho de televisão permanentemente ligado no final do pequeno labirinto formado pelo Penetrável PN3 e tecidos estruturados como paredes para seu acesso. A proposta era que aqueles que quiserem experimentar a obra tirassem seus sapatos e explorassem descalços a construção.

PN2 - A Pureza é um Mito é um Penetrável simples, uma caixa em que cabe um adulto e que tem a inscrição que leva seu nome na parte de cima. Essa noção de pureza pode ser pensada dentro do contexto da Tropicália como uma crítica ao racionalismo excessivo da forma, mas também como uma observação à impossibilidade da existência de uma 
"cultura pura", resultante da dicotomização entre alta cultura burguesa e cultura popular, onde a cultura popular seria algo genuíno, puro. Em definição do sociólogo britânico-jamaicano Stuart Hall "A cultura popular não é, num sentido 'puro', nem as tradições populares de resistência a esses processos [de modernização], nem as formas que as sobrepõem"35. O popular é o lugar do embate, o terreno onde ocorrem as transformações da cultura e não é nada estanque, original, primário. A Pureza é um mito também é uma crítica ao uso que o modernismo brasileiro havia feito do popular: representações de populares como o lugar o ingênuo, do infantil, daquilo que precisava ser tutelado.

O percurso proposto pelo PN3 - Penetrável Imagético se inicia em uma pequena área sem teto em que o espectador lida com elementos sensoriais, toca capim-cheiroso e manipula maços de palha. Segue-se por uma parte escura com chão areia e uma cortina de tiras de plásticos - dessas usadas em portas de cozinhas de casas suburbanas para dividir os ambientes. Ao vencer as cortinas, o espectador se depara com uma televisão ligada, mas sem sintonizar nenhum canal. As luzes bruxuleantes da televisão mal sintonizada tinham o sentido proposital de devorar e confundir o espectador, que vinha do breve túnel escuro, e ativar seu sensorial.

A questão sensorial é combinada o tempo inteiro com elementos retirados do cotidiano da favela, com imagens da chamada cultura de massas (uma televisão, no caso), com elementos representantes de uma brasilidade associada ao tropical (duas araras e plantas tropicais como espada-de-são-jorge, por exemplo) e elementos poéticos. Podemos dizer que ele sintetiza a noção de cultura híbrida ao unir as esferas e superar a separação entre "popular" e "erudito". Ao levar para dentro do museu os elementos que não eram pensados como obras de arte (por exemplo, os vasos de planta e as araras) Oiticica não realiza simples readymades. A assimilação da cultura popular como objeto artístico (e não apenas "antropológico") marca a contribuição de Tropicália para a tradução de certa brasilidade, entre o moderno e o contemporâneo, rústica e televisiva ao mesmo tempo.

35 Hall, Stuart. Notas sobre a desconstrução do popular. In Da diáspora: identidades e mediações culturais. Belo Horizonte: Editora UFMG, 2003, p. 231-247. 
Imagem 5

Tropicália,

Penetráveis PN2 e

PN3, 1967

Museu de Arte

Moderna do Rio de

Janeiro in Dercon,

1996, p. 122

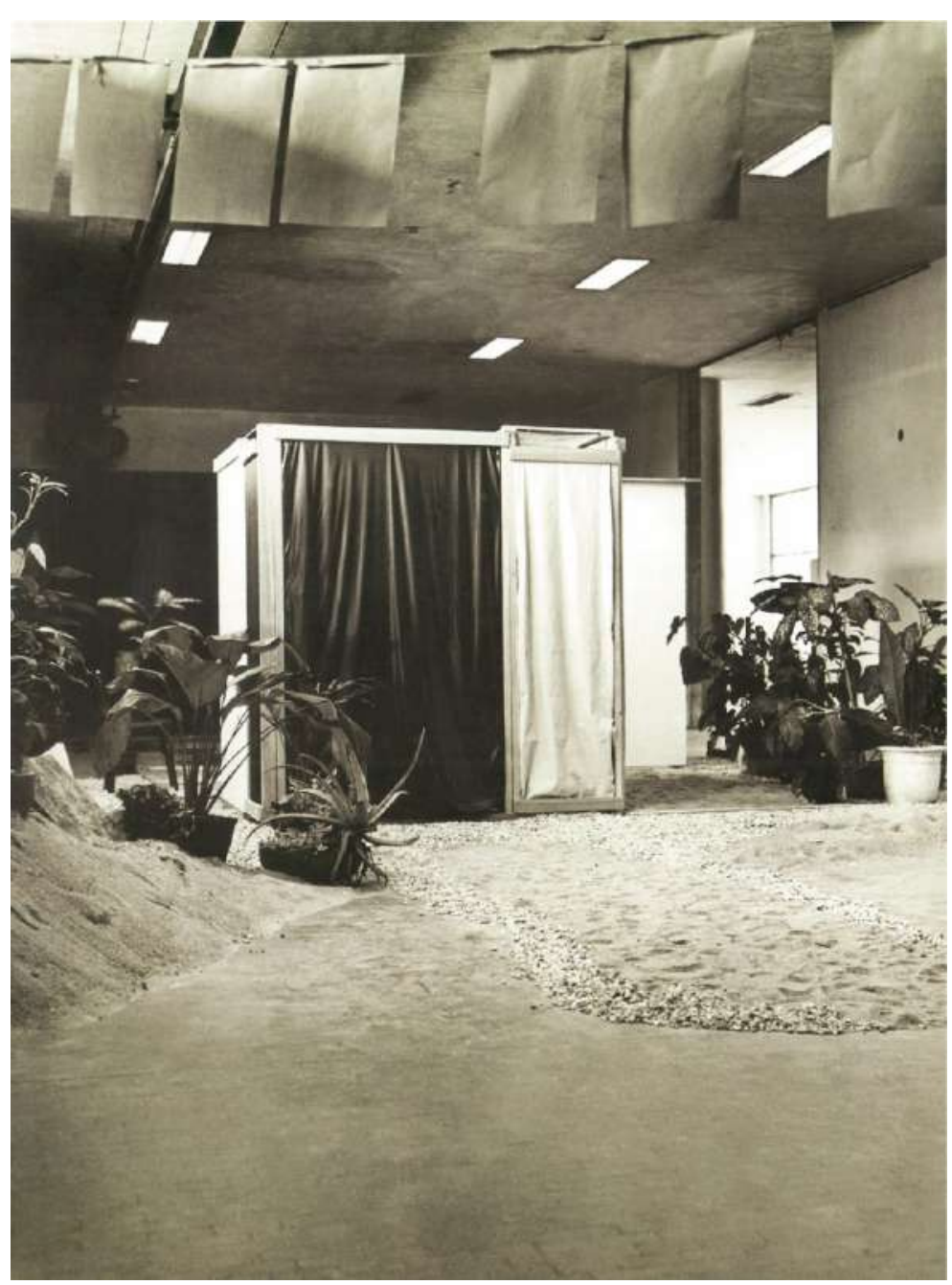

A ativação dos sentidos, com estímulos dos pés descalços à cabeça, e a reprodução do ambiente da favela, simulacro das experiências de Oiticica na Mangueira eram os objetivos dessa exposição. O artista queria replicar o poder telúrico da sua experiência no Morro. Na entrada de 15 de maio de 1967 em seu diário, sob o título "Perguntas e respostas para Mário Barata. (Fragmentos)", o artista revela que a experiência da Tropicália foi fundamental para ele levar adiante seus desejos:

(...) para entrar em cada Penetrável era o participador obrigado a caminhar sobre areia, pedras de brita, procurar poemas por entre as folhagens, brincar com araras etc. - o ambiente criado era obviamente tropical, como que num fundo de chácara, e, o mais importante, havia a sensação de que se estaria de novo pisando a terra. Esta sensação sentia eu anteriormente ao caminhar pelos morros, pela favela, e mesmo o percurso de entrar, sair, dobrar 'pelas quebradas' da Tropicália, lembra muito as caminhadas pelo morro (lembro-me aqui de que, um dia, ao saltar do ônibus ao pé do morro da Mangueira com dois amigos meus, [o poeta] Raimundo Amado e sua esposa llíria, esta observou de modo genial: 'tenho a impressão de que estou pisando outra vez a terra' - esta observação guardei para sempre pois revelou-me naquele momento algo que não conseguira formular apesar de sentir e 
que, concluí, seria fundamental para os que desejarem um 'descondicionamento' social) $[. .$.$] quero fazer o homem voltar à terra"36$

Gostaria de insistir na ideia de experiência telúrica da terra, materializada pela Mangueira, pois reúne a busca - e encontro - pela estrutura, pelo orgânico e pelo adverso encontrados por Oiticica na sua vivência na favela. A terra, oposição romântica ao urbano industrializado, também aparece em um dos seus primeiros Bólides como matéria do estímulo sensoria| ${ }^{37}$. Novamente, em seus manuscritos, em 1978 Oiticica descreve o projeto "Devolver a terra à terra", lançando nova ordem de trabalho, o Contra-Bólide. A mudança dá-se basicamente na possibilidade da obra ser repetida e não se dar de forma conclusiva. "Programa-obra in progress" é a possibilidade de refazer a gênese da obra em outra ocasião. Isto é: conceber uma obra com várias gêneses. Hélio Oiticica explica ainda o significado simbólico de deslocar uma terra de um lugar para outro, colocando-a numa fôrma sem fundo ${ }^{38}$. A associação da terra à "gênese", tanto como origem quanto possibilidade de jamais se repetir enquanto obra aberta, em constante mutação, perdura, portanto, ao longo de décadas na obra do artista. Voltar a terra seria devolver ao homem a sua essência, condição esta que o artista havia encontrado ao frequentar as margens da cidade e nas ladeiras e becos da favela do Morro da Mangueira.

\section{Conclusão}

Em fins de 1963, Oiticica não descobriria a Mangueira como um mero lugar. A Mangueira era o encontro com a expressão que ele tanto perseguia e a possibilidade da obra de arte total. Isso aconteceria não somente pela música - aspecto norteador para a elaboração de suas obras, mas também pelo seu entendimento de não haver uma hierarquia de importância e valores entre a cultura popular do samba mangueirense e o ambiente cultural na qual ele havia crescido. Falamos então de duas questões para que Hélio Oiticica não apenas chegasse, mas se encontrasse na Mangueira: a mudança do seu entendimento da cultura

\footnotetext{
36 Oiticica, 1980, p. 99.

${ }^{37}$ Bólide Vidro 4, Terra, 1964.

38 Oiticica, Hélio. Devolver a terra à terra. Caderno Manuscrito, 1978. Projeto Hélio Oiticica $0123 / 78-2 / 2$.
} 
popular e a visão de que era nesse outro tipo de obra de arte - até então minimizado pela dita cultura erudita - que ele encontraria o caminho para as suas questões artísticas.

Esse encontro com a Mangueira foi, para Oiticica, o encontro com o real. É no popular que ele vive. A resposta estaria no cotidiano, e o Parangolé expressa isso.

A palavra Parangolé - conversa fiada, papo sem importância, abobrinha - combina autoironia e referência ao coloquial cotidiano, àquilo que nos diálogos é mais forte que o conteúdo intercambiado: o simples estar ali, lado a lado com o outro. ${ }^{39}$

O uso que Oiticica faz dos objetos e materiais cotidianos e populares não é resultado somente de "fascínio" ou admiração pelo ordinário. Ele usa o cotidiano vulgar para resolver questionamentos artísticos e também para exteriorizar, por intermédio de suas obras, questionamentos políticos, sociais, críticas ao circuito artístico e às vanguardas modernistas. Hélio Oiticica não queria apenas que sua arte se confundisse com a vida; queria que ela a ampliasse e intensificasse. recalcada da dualidade ontológica. Antropofagia, dialogia criativa, abertura participativa e expansão do repertório. In: Cocco, Guiseppe et alii (org). Hélio Oiticica para além dos mitos. Rio de Janeiro: R\&L Produtores Associados, 2016. p. 58. 